\title{
The Influence of Supervision on the Performance of Associate Nurse in Hospitals : a Literature Review
}

\author{
Munawar $^{1}$, Ariyanti Saleh ${ }^{2}$, Rini Rachmawaty ${ }^{2}$ \\ ${ }^{I}$ Postgraduate Student, Faculty of Nursing, Hasanuddin University; Indonesia \\ ${ }^{2}$ Faculty of Nursing, Hasanuddin University, Indonesia \\ Corresponding author: kalmaliq@gmail.com
}

\begin{abstract}
ABSTRAK
Background: Various efforts are made to maintain and improve the quality of nursing services, one of which is to carry out nursing care according to the standards of nursing practice safely, effectively and ethically. To maintain quality, it is necessary to control nursing care in a directed and planned manner. One of the controls in nursing management is supervision.

Purpose: The purpose of this literature study is to identify the effectiveness of the implementation of supervision on the performance of implementing nurses in hospitals.

Methods: Database searches used in this literature review are Pubmed, Science Direct and Google Scholar published in 2007-2018.

Results: From the six articles used, it was found that supervision had an impact on improving nurses' performance in the form of actions and behaviors that could be measured to maintain and improve the quality of health services for both sick and healthy patients. Other impacts among them commitment, employee attachment, competence and individual quality as well as improving service qualityto them after completing the credentialing process as stated in the Nurse Clinical Assignment Letter.

Conclusion: Implementation of supervision motivates nurses to be more attached to work, and has better performance opportunities.
\end{abstract}

Keywords: Performance, Quality of nursing care, Supervision.

Received: December 04, 2018; Revised : December 12, 2018; Accepted: December 17, 2018

How to Cite: Munawar, M., Saleh, A., \& Rachmawaty, R. (2019). The Influence of Supervision on the Performance of Associate Nurse in Hospitals : a Literature Review. Journal of Nursing Practice. 2(2). 91-96. https://doi.org/10.30994/jnp.v2i2.47 


\section{BACKGROUND}

In general, the success of hospitals in carrying out their functions of providing quality health services is influenced by several factors. One of the most influential is human resources who play a role in the hospital environment as the main asset of the hospital because it acts as a driving force in the organization(Sahoo \& Mishra, 2012). Nurses are one of the largest resources among all health workers and are directly involved with patients for 24 hours (Torabinia, Mahmoudi, Dolatshahi, \& Abyaz, 2017; Vagharseyyedin, Vanaki, \& Mohammadi, 2011). Nurses handle almost $90 \%$ of health services in hospitals with nursing care so that it plays an important role in patient outcomes. If nurses are managed and monitored well, nurses can work professionally and make a major contribution to maintaining and improving the quality of the hospital.

In order to be able to realize and improve high-quality nursing services, several attempts were made, one of which is that nurses must be able to carry out nursing care by paying attention to ethical and moral principles and according to safe, effective and ethical standards (PPNI, 2005). Efforts to maintain quality are carried out in a directed and planned manner and require the proper control of nursing care (Marquis \& Huston, 2012). One of the controls carried out in nursing management is supervision, which is a place to guide and improve the competence of supervised parties so that they are able to carry out the tasks or jobs that have been determined effectively and efficiently (Nursalam, 2015)

Supervision as a formal process and a form of professional support for nurses in the development of knowledge, ability, accepting responsibility in practice and increasing protection of patients so that safe nursing services are realized according to policies and procedures in complex situations (Sitorus \& Panjaitan, 2011). This is in accordance with the research conducted by Widiyanto, Hariyati, \& Handiyani (2013) showed that after the application of clinical supervision there was a significant increase in the quality of wound care measures between groups given treatment in the form of training and not given training treatment $(\mathrm{p}=0.001)$ and there was an influence of supervision on the quality of wound care measures $(p=0.005 ; \mathrm{r}=0.613 ; \alpha=0.05)$.

Performance-related issues have always been a conversation in the community, lack of performance or nursing services is a global issue (Lee et al., 2017). The good performance of nurses is a pioneer in improving the quality of health services provided to patients both sick and healthy (Mulyono, Hamzah, \& Zulkifli, 2013). For this reason, this article will discuss the application of supervision that influences the performance of nurses in nursing services.

\section{METHODS}

This literature review analyzes relevant articles and focuses on the implementation of supervision that affects the performance of nurses in nursing services. The articles used in this literature review are articles obtained using 3 databasesPubmed, Google Scholar dan Science Directby entering keywords"supervision", "nursing job", "job performance", "critical thinking"and "selfconfidence".The articles used are 6 articles published in the last six years

\section{RESULTS}

From the literature review, it was revealed that the effectiveness of supervision on nurses 'performance resulted in work commitment and attachment and had an impact on the competence and quality of nurses' work. These will be discussed as follows: 


\section{Commitment and work engagement}

Research with survey methods is carried out by Koivu, Saarinen, \& Hyrkas (2012) revealed that of $114(48.7 \%)$ nurses $(n=304)$, those who received clinical supervision efficiently revealed that $50 \%$ reported supervision was a good evaluation of work and health. Where the supervision provides more controlled and personalized work felt by nurses more motivated, committed to the organization and more tied to work and less experienced fatigue than their peers. The role of clinical supervision can be conceptualized as additional work related to other work and personal resources, which strengthen each other, promote well-being in the workplace. Efficient clinical supervision may be one of the antecedents and consequences of well-being in the workplace.

While qualitatively, research was conducted by Watson, Macdonald, \& Brown (2013) who explore FGD between nurse experts and beginners about nurse readiness and evaluation of clinical supervision. The results obtained found that novice nurses criticized the reality of clinical supervision, namely lack of readiness to participate, uncertainty and resistance. The elements in clinical supervision design, especially time, frequency, and choice of expert participants if well designed, will encourage the attachment of beginner nurses well. All participants made recommendations to improve the implementation of the clinical supervision program. However, this study cannot be generalized because the small sample elements and this evaluation were first carried out on the implementation of clinical supervision.

\section{Nurse competency and quality}

According to research conducted by Elzeneny, Seada, \& Aleametewy (2017) with the aim of examining the effect of the supervision training program, it was found that there was a statistically significant correlation between nurses' clinical supervision competencies and the quality of patient care among nursing staff immediately after implementing the program and 3 months after the program. So the recommendations obtained from this study are that adequate support from nurse managers and the resources needed to facilitate the implementation of clinical supervision and motivate them to implement new education clinical supervision strategies so as to improve the quality of patient care.

In longitudinal and exploratory descriptive studies carried out by Cruz (2011) to all chief room to assess the appropriate instrument for supervision and how the instrument is able to evaluate supervision effectively. The results showed that there were statistically significant differences of opinion after the application of the Portuguese version of the Clinical Supervision Scale and the Manchester Clinical Supervision Scale on all dimensions of the scale. The recommendations given are clinical supervision in nursing must be an obligation for every nurse in clinical practice because the positive effects cannot be denied but the clinical supervision process must be monitored systematically with accurate instruments such as the Manchester Clinical Supervision Scale

Research conducted by Circenis et al.,(2015) to evaluate the effectiveness of nurse practitioner supervision in hospitals with quantitative methods using control groups and experiments to measure fatigue during supervision sessions. The results obtained showed that there were statistically significant differences between emotional fatigue and depersonalization indicators in participants in the experimental group before and after supervision and between the experimental group and control group indicators after supervision. Supervision decreased the saturation index 
in the experimental group compared to the control group. Supervision is also useful for nurses to always improve themselves, control emotions and various aspects of behavior at work.

Meanwhile, research was conducted by Cruz, Carvalho, Lamas, \& Barbosa, (2014) with the aim of research to see the results of the implementation of nursing care, especially in the care of patients the risk of falls if supervised. The results showed that $16.7 \%$ of patients showed "no risk of falls", $48.5 \%$ had "risk of falling low" and 34.8\% had "high risk of falls". Another finding was that there was a mismatch in implementing the Morse Fall Scale application protocol. So, the recommendations of this study as a contribution to the supervision model of both individual and group supervision in improving patient care because nurses can actively participate and reflect on their practice. These strategies can ensure that nurses develop nurse clinical practice based on the best scientific evidence

\section{DISCUSSION}

The results found in this literature are supervision can increase commitment and work engagement. Nurses as employees who have high work attachments will work in accordance with the commitment to focus on goals, use intelligence in making decisions, be responsible for a task, monitor their behavior to determine what is done right and in accordance with the goals and standards to be achieved and will correct if there is an error made (Bakker \& Leiter, 2011). Nurses as the most professions and are directly involved are determinants of hospital health services so that if nurses are managed and monitored properly, nurses can work professionally and make a large contribution to maintaining and improving the quality of hospitals. Through supervision activities, working conditions are optimally managed, more conducive and comfortable which includes the physical environment, work atmosphere, and the number of resources needed to facilitate the implementation of tasks.

Supervision also in the literature review has an impact on the competence and quality of nurses. Supervision is the main determinant of service quality and service provider performance, and is mainly related to low resource arrangements where supervisors are very important for the performance of health workers(Purity, Eilish, Ogenna, Honorati, \& Henry, 2017). Performance is a measure of the success of health services that shows the accountability of service institutions in this case is hospitals. According to Borman and Motowidlo (1997) in Muindi \& K'Obonyo, (2015) stated that employee performance is in the form of actions, behaviors and measurable results where employees are bound or what employees do related to organizational goals and contribute to organizational goals.

\section{CONCLUSION}

Literature review on supervision produces two themes, namely supervision can increase commitment and work engagement and have an impact on competency and quality of nurses. It is important for service institutions to pay attention to supervision activities, with supervision contributing to the achievement of organizational goals.

\section{REFERENCES}

Bakker, A. B., \& Leiter, M. P. (2011). Work Engagement : A Handbook of Essential Theory and Research (1st ed.). London: Psychology Press. 
Circenis, K., Jeremejeva, J., Millere, I., Deklava, L., Paparde, A., \& Sudraba, V. (2015). Supervision in Nursing: Latvian Sample Study. Procedia - Social and Behavioral Sciences, 205(May), 86-91. https://doi.org/10.1016/j.sbspro.2015.09.023

Cruz, S., Carvalho, L., Lamas, B., \& Barbosa, P. (2014). Improving Quality in the Patients "e Risk of Fall Evaluation through Clinical Supervision. International Journal of Information and Education Technology, 4(6), 526-530. https://doi.org/10.7763/IJIET.2014.V4.463

Cruz, S. S. S. M. (2011). Clinical supervision in nursing: Effective pathway to quality. Procedia - Social and Behavioral Sciences, 29(Iceepsy), 286-291. https://doi.org/10.1016/j.sbspro.2011.11.240

Elzeneny, S. R., Seada, A. M., \& Aleametewy, E. El. (2017). Effect of Clinical Supervision Training Program for Nurse Managers on Quality of Nursing Care in Intensive Care Units. International Journal of Didactics, 07(8.244).

Koivu, A., Saarinen, P. I., \& Hyrkas, K. (2012). Who benefits from clinical supervision and how? The association between clinical supervision and the work-related well-being of female hospital nurses. Journal of Clinical Nursing, 21(17-18), 2567-2578. https://doi.org/10.1111/j.1365-2702.2011.04041.x

Lee, Y. W., Dai, Y. T., Chang, M. Y., Chang, Y. C., Yao, K. G., \& Liu, M. C. (2017). Quality of Work Life, Nurses' Intention to Leave the Profession, and Nurses Leaving the Profession: A One-Year Prospective Survey. Journal of Nursing Scholarship, 49(4), 438-444. https://doi.org/10.1111/jnu.12301

Marquis, B. L., \& Huston, C. J. (2012). Leadership Roles and Management Function in Nursing Theory and Aplication (7th ed.). Philadephia, USA: Lippincott Williams \& Wilkins.

Muindi, F., \& K'Obonyo, P. (2015). Quality of Work Life, Personality, Job Satisfaction, Competence, and Job Performance: a Critical Review of Literature. European Scientific Journal, 11(26), 225-240.

Mulyono, M. H., Hamzah, A., \& Zulkifli, A. A. (2013). Faktor yang Berpengaruh terhadap Kinerja Perawat di Rumah Sakit Tingkat III 16.06.01 Ambon. Jurnal AKK, 2(1), 18-26.

Nursalam. (2015). Manajemen Keperawatan : Aplikasi dalam Praktik Keperawatan Profesional (3rd ed.). Jakarta: Salemba Medika.

PPNI. (2005). Standar Praktik Persatuan Perawat Nasional Indonesia (PPNI). Ppni, (15), 1-65.

Purity, M., Eilish, M., Ogenna, U., Honorati, M., \& Henry, M. (2017). The Impact of Supportive Supervision on the Implementation of HRM processes; A Mixed-Methods study in Tanzania. Health Systems and Policy Research, 04(01), 1-9. https://doi.org/10.21767/22549137.100066

Sitorus, R., \& Panjaitan, R. (2011). Manajemen Keperawatan : Manajemen Keperawatan di Ruang Rawat. Jakarta: Sagung Seto.

Torabinia, M., Mahmoudi, S., Dolatshahi, M., \& Abyaz, M. R. (2017). Measuring engagement in nurses: The psychometric properties of the Persian version of Utrecht Work Engagement Scale. Medical Journal of the Islamic Republic of Iran, 31. https://doi.org/10.18869/mjiri.31.15

Vagharseyyedin, S. A., Vanaki, Z., \& Mohammadi, E. (2011). The Nature Nursing Quality of Work Life : An Integrative Review of Literature. Western Journal of Nursing Research, 33(6), 786-804. https://doi.org/10.1177/0193945910378855

Watson, J., Macdonald, G. J., \& Brown, D. (2013). Clinical supervision for novice millennial 
nurses in the perinatal setting: The need for generational sensitivity. Open Journal of Nursing, 3(September), 373-378. https://doi.org/10.4236/ojn.2013.35050

Widiyanto, P., Hariyati, R. S. T., \& Handiyani, H. (2013). Pengaruh Pelatihan Supervisi terhadap Penerapan Supervisi Klinik Kepala Ruang dan Peningkatan Kualitas Tindakan Perawatan Luka Di RS PKU Muhammadiyah Temanggung. Prosiding Konferensi Nasional PPNI Jawa Tengah, 44-51. Retrieved from http://jurnal.unimus.ac.id/index.php/psn12012010/article/viewFile/848/902 